\title{
Mekanisme Penetapan Kebijakan Pengupahan di Indonesia: Suatu Tinjauan Perbandingan Hukum
}

\author{
A. Uwiyono
}

\begin{abstract}
At the praxis level, the Indonesian labor relations have not been reaching a coalition. stage. Therefore democracy at work should be developed in order to prevent the industrial relations from adversarial one. There are some kinds of worker participation to improve the relationship between the labor and the laborer, such as peacefull collective bargaining, Works Council or Board of Directors involvement and also Employee stock ownership plan. This kind of partnerships will create a democratic treatment for any labor issues in Indonesia.
\end{abstract}

\section{Pendahuluan}

Globalisasi ekonomi yang ditandai dengan persaingan yang semakin ketat, transparansi, dan lebih demokratis, telah menempatkan Indonesia sebagai negara berkembang pada posisi yang serba dilematis dalam menangani masalah perburuhan. Di satu pihak negaranegara berkembang yang berada pada posisi tergantung pada modal dan teknologi negara maju, terpaksa menekan tingkat upah dan syarat-syarat kerja lainnya untuk menarik penanam modal asing (foreign investor). Di lain pihak mereka ditekan oleh negara-negara maju untuk memperhatikan upah buruh serta syarat-syarat kerja dan kondisi kerja lainnya melalui berbagai macam cara. Misalnya, ancaman pencabutan quota ekspor ataupun melalui penerapan social clause yang selalu diusulkan untuk diagendakan dalam setiap sidang WTO. ${ }^{1}$ Amerika Serikat beberapa kali mengancam akan mencabut kuota ekspor tekstil ke Amerika Serikat karena pemerintah Indonesia tidak menjamin hak buruh untuk

"Lance Compa. "Labor Right and Labor Standards in International Trade." Law and Policy in International Business. 25 (Fall 1993, No.1). HIm. 181. 
berserikat ataupun pelaksanaan peraturan perundang-undangan yang menekan buruh, serta rendahnya upah di Indonesia: ${ }^{2}$

Tekanan terhadap negara-negara berkembang ini juga muncul dari gerakan buruh di dalam negeri yang menuntut reformasi hukum di bidang perburuhan, termasuk perbaikan upah dan kesejahteraan mereka beserta keluarganya. Hal ini ditandai dengan maraknya pemogokan yang menuntut kenaikan upah dan perbaikan kesejahteraan buruh lainnya. ${ }^{3}$ Pada era pasca pemerintahan Suharto, tekanan baik dari dalam negeri maupun dari luar negeri ini bukannya semakin surut melainkan justru semakin kuat. Menghadapi tekanan baik dari luar maupun dari dalam negeri tersebut, pemerintahan Habibie maupun pemerintahan Abdurrachman Wahid mendorong berkembangnya demokratisasi di tempat kerja melalui pembaruan terhadap peraturan perundangundangan yang mengatur masalah keserikatburuhan dan meratifikasi Konvensi ILO yang mengatur Hak Fundamental Buruh. Dengan demikian, pemerintah Indonesia telah meratifikasi seluruh Konvensi inti ILO, ${ }^{4}$
Proses demokratisasi di tempat kerja ini tampaknya masih berjalan tersendat-sendat. Kenyataan menunjukkan bahwa dewasa ini sedang terjadi polemik mengenai penetapan ketentuan upah minimum yang ditetapkan oleh pemerintah. Pengusaha melalui APINDO (Asosiasi Pengusaha Indonesia) dengan gigih menolak melaksanakan ketentuan Upah Minimum DKI. ${ }^{5}$ Bahkan menggugat Gubernur DKI ke Pengadilan Tata Usaha Negara. Maksud gugatan ini adalah agar Pengadilan Tata Usaha Negara membatalkan keputusan Gubernur tentang Upah Minimum Propinsi. ${ }^{\circ}$ Sebaliknya buruh-buruh di sektor perkayuan di Pontianak menolak Surat Keputusan Gubernur No.: 11 Tahun 2002 tentang Upah Minimum yang menetapkan Upah Minimum di Provinsi Kalimantan Barat sebesar Rp. 380.000 ,--1bulan. Surat Keputusan ini merubah Surat Keputusan Gubernur No. 408 Tahun 2001 yang telah menetapkan UMP sebesar Rp. 430:000,-/bulan. Protes serupa juga dilakukan buruh-buruh perkayuan di Samarinda yang menuntut agar upah minimum disesuaikan dengan kebutuhan hidup minimum yang telah ditetapkan oleh BPS Kalimantan Timur sebesar Rp.633.625,-i bulan. ${ }^{7}$ Polemik tentang ketentuan upah mini-

2Dibandingkan dengan negara-negara ASEAN, upah buruh Indonesia adalah terendah. Upah buruh tekstil di Singapura: US\$3,1/jam, Malaysia: US\$2/jam, Filippina: US\$1,1/jam, Thailand: USS1,7/jam, Vietnam: US\$0,35/jam, Indonesia: 0,285/jam. Kompas. 5 November 2001. HIm. 4.

3Jumlah pemogokan di Indonesia sejak 1995 sampai dengan April 2000 berjumlah 1.326 kali, melibatkan 715.352 buruh. Data ini diolah dari Laporan Tahunan tentang Perkembangan Kasus Pemogokan yang dikeluarkan oleh Direktur Jenderal Binawas Departemen Tenaga Kerja RI dari 1995 sampai dengan April 2000.

${ }^{4}$ Konvensi Inti ILO yang telah diratifikasi oleh pemerintah Indonesia adalah Konvensi ILO No. 87, 98, 100 , $111,29,105.138$, dan 182.

${ }^{5}$ Kompas. 23 November 200. Him. 13.

${ }^{6}$ Kompas. 14 Desember 2001. HIm. 14.

${ }^{7}$ Kompas. 29 Januari 2002. HIm. 20. 
mum tersebut memberikan indikasi bahwa hubungan perburuhan di Indonesia masih bersifat permusuhan (adversarial relation). Polemik ini terjadi setiap tahun bahkan pada tahun-tahun mendatang polemik tentang besarnya upah minimum ini akan muncul kembali. ${ }^{8} \mathrm{Hal}$ ini disebabkan oleh campur tangan pemerintah yang terlalu besar mempersulit pemerintah sendiri dalam menetapkan ketentuan yang adil.

Artikel ini bermaksud untuk memberikan ide tentang jalan keluar bagaimana hukum dapat berperan untuk mencegah terjadinya polemik antara buruh dan pengusaha tentang permasalahan buruh yang krusial khususnya masalah upah.

Untuk menganalisis permasalahan tersebut di atas, artikel ini mendasarkan pada asumsi bahwa hubungan kerjasama buruh dan pengusaha pada dasarnya disebabkan oleh adanya hubungan ketergantungan (mutual symbiosis) antara buruh dan pengusaha itu sendiri. Dengan demikian, hubungan buruh dan pengusaha adalah hubungan kerjasama, bukan, hubungan konflik yang bersifat abadi. - Melalui perundingan bersama, buruh dan pengusaha dapat saling memberikan konsesi yang pada gilirannya akan menjadi faktor pendorong hubungan kerjasama antara buruh dan pengusaha dapat tercipta dan berjalan efektif. ${ }^{9}$ Meskipun kedudukan sosial ekonomi buruh lebih lemah dibandingkan dengan kedudukan sosial ekonomi pengusaha, dan dilihat dari segi hubungan hukumnya bersifat timpang, namun hubungan kerjasama buruh dan pengusaha merupakan dasar terjadinya hubungan kerja. It is not true, the parties to industry are in reality not enemies, but partners; they have a common interest, no one can get on without the others. ${ }^{10}$ Oleh karena itu, pemerintah tidak perlu banyak campur tangan dalam menentukan upah, kondisi kerja, serta syarat-syarat kerja lainnya. Peran pemerintah sebaiknya hanya sebatas mengembangkan hubungan kerjasama buruh dan pengusaha melalui 'ketentuan-ketentuan hukum yang dimaksudkan untuk itu.

\section{Mengembangkan Partisipasi Buruh melalui Democracy at Work}

Hubungan kerjasama antara buruh dan pengusaha ini secara faktual dapat dilihat dalam bentuk partisipasi yang dilakukan oleh

'8ada 1997, APINDO, APRESINDO, bahkan Menko PRODIS menolak kenaikan upah minimum yang ditetapkan Pemerintah (Menaker) sebesar 10,57\% untuk wilayah JABOTABEK. Harian Merdeka. 23 Januari 1997. Hlm. 1. Penolakan APINDO terhadap ketentuan upah minimum ini terjadi lagi pada 2001, bahkan APINDO telah menggugat Gubernur DKI, Gubernur Jawa Barat ke Pengadilan Tata Usaha Negara agar membatalkan atau menunda pelaksanaan Surat Keputusan Gubernur yang menetapkan Upah Minimum. Kompas. 23 November 2001. HIm. 13.

${ }^{9}$ Owen E. Herrnstadt. "Why Some Union Hesitate to Participate in Labor-Management Cooperation Prrograms." The Labor Lawyer 8. (Winter, 1992, No.1). HIm. 78-79.

10John D. Rockefeller jr. "Cooperation in Industry." International Labour Review 135 (1996, No. 3-4). HIm. 293. Lihat pula Payaman J. Simanjuntak. 2000. Peranan Serikat Pekerja dan Paradigma Baru Hubungan Industrial di Indonesia. Jakarta: Himpunan Pembina Sumberdaya Manusia Indonesia. Hilm. 62. 
buruh (worker participation). Dalam hal ini terdapat beberapa bentuk partisipasi buruh di tingkat perusahaan. Pertama, partisipasiburuh yang tercermin dalam keikutsertaan buruh dalam menentukan upah, syarat-syarat kerja, dan kondisi kerja lainnya melalui perundingan kolektif secara damai (peacefull collective bargaining). Kedua, partisipasi buruh yang tercermin dalam keikutsertaan buruh dalam menentukan kebijakan perusahaan yang bersifat managerial melalui Dewan Kerja (Works Council) atau Dewan Direktur (Board of Directors). Ketiga, partisipasi buruh yang tercermin dalam keikutsertaan buruh dalam kepemilikan saham perusahaan melalui Program Kepemilikan Saham bagi 'Buruh (Employee Stock Ownership Plan).

Ketiga bentuk partisipasi buruh tersebut di atas merupakan fora atau media untuk meningkatkan hubungan kerjasama antara - buruh dan pengusaha. Melalui kerjasama dalam menetapkan ketentuan-ketentuan tentang upah, syarat-syarat kerja serta kondisi kerja lainnya, yang dituangkan dalam perjanjian perburuhan, maka buruh dan pengusaha akan mendapatkan ketentuan yang paling objektif. Sehingga dalam kondisi demikian ini kepastian hukum di tempat kerja dapat diciptakan, kegairahan kerja dapat ditingkatkan, dan hubungan kerjasamá dapat meningkat. Selanjutnya melalui kerjasama buruh dan pengusaha dalam menentukan kebijakan perusahaan yang bersifat managerial, buruh tidak dianggap seba'gai faktor ekstern perusahaan, melainkan sebagai faktor intern perusahaan. Hal ini pada gilirannya akan dapat menumbuhkan rasa memiliki (sense of belonging) dan rasa tanggung jawab (sense of responsibility) terhadap perusahaan dimana mereka bekerja. Kebijakan perusahaan yang bersifat manajerial antara lain mencakup rencana produksi, metode berproduksi, pembaruan teknologi, dan peningkatan efisiensi."

Melalui program kepemilikan saham, buruh benar-benar merupakan faktor intern perusahaan, sehingga segala daya upaya akan dilakukan - oleh buruh untuk meningkatkan kemajuan perusahaan agar perusahaan meraih untung yang sebesarbesarnya. Dengan kata lain, rasa memiliki dan rasa tanggung jawab terhadap perusahaan dari kaum buruh akan.semakin besar, karena mereka merupakan salah seorang pemilik perusahaan dimana mereka bekerja.

Kerja sama buruh dan pengusaha dalam menetapkan upah, syarat-syarat kerja, dan kondisi kerja lainnya ini pada tataran internasional dijamin oleh berbagai instrumen hukum. Hal ini tercermin dalam beberapa Konvensi maupun Rekomendasi ILO yang mendorong hubungan kerjasama antara buruh dan pengusaha dalam menetapkan ketentuan-ketentuan hukum yang mengatur hak dan kewajiban mereka.

Pertama, konvensi ILO No.. 98 tentang Kebebasan Berserikat dan Berunding Bersama menjamin hak buruh untuk ikut serta menentukan upah dan syarat-syarat kerja atau kondisi kerja di perusahaan dimana mereka bekerja. Hal ini tercermin dalam. Pasal 4 Konvensi ILO No. 98 yang menyatakan:

"Leroy Merrifield'. "Worker Participation in Decisions Within Undertakings." Comparative Labor Law5, (Winter, 1982, No.1). HIm. 20. 
Measures appropriate to national conditions shall be taken: where necessary, to encourage and promote the full development and utilisation of machinery for voluntary negotiations between employers or employers' organisations and workers' organisations. with a view to the regulations of terms and conditions of employment by means of collective agreements.

Kedua, Rekomendasi ILO No. 91 tentang Perjanjian Kolektif yang mengamanatkan kepada negara untuk menjamin hak buruh untuk berunding dan membantu para pihak dalam berunding, merevisi, atau memperbarui perjanjian kolektif. Hal ini tercermin dalam Pasal 1 ayat (1) yang menyatakan:

Machinery appropriate to the conditions existing in each country should be established, by means of agreement or laws or regulations as may be apprporiate under national conditions, to negotiate, conclude, revise and renew collective agreements, or to available to assist the parties in the negotiation. conclusion, revision and renewal of collective agreements.

Ketiga, Rekomendasi ILO No. 94 tentang Konsultasi dan Kerjasama antara Pengusaha dan Buruh pada tingkat Perusahaan mengamanatkan kepada negara anggota ILO untuk mendorong terbentuknya hubungañ kerjasama antara pengusaha dan buruh dalam membahas kepentingan bersamà di luar materi perjanjian perburuhan. $\mathrm{Hal}$ ini tercermin dalam Pasal 1 Rekomendasi ILO No. 94 yang menyatakan:

Appropriate steps should be taken to promote consultation and co-operation between employers and workers at the level of undertaking on matters of mutual concern not within the scope of collective bargaining machinary, or not normally dealt with by other machinary concerned with the determination of terms and conditions of employment.

Keempat, Rekomendasi No. 129 tentang Komunikasi antara Manajemen dan Buruh dalam suatu Perusahaan mengamanatkan kepada negara anggota ILO untuk menjamin berjalannya komunikasi antara buruh dan menejemen di tingkat perusahaan. Hal ini tercermin dalam Pasal 3 Rekomendasi ILO No. 129 yang menyatakan:

An effective policy of communication should ensure that information is given and that consultation takes places between the parties concerned before decisions on matters of major interest are taken by management, in so far as disclosure of the information will not cause damage to either party.

Kelima, Konvensi ILO No. 113 Tahun 1960 tentang Konsultasi dan Kerjasama antara Penguasa, Organisasi Buruh, dan Organisasi Pengusahä pada Tingkat Industri dan Tingkat Nasional, mengamanatkan kepada negara anggota ILO agar mengembangkan dialog sosial (social dialogue) antar para pelaku produksi yaitu buruh, pengusaha, dan penguasa. Hal ini tercermin dalam Pasal 1 ayat (1) Konvensi ILO No. 113 yang menyatakan:

Measures appropriate to national conditions should be taken to promote effective consultation and co-operation at the industrial and nationals level between public authorities and employers' and workers' 
organisation, as well as between these organisations, for the purposes indicated in paragraphs 4 and 5 below, and such other matters of mutual concern as the parties may determine.

Dari kelima Konvensi dan Rekomendasi ILO tersebut di atas, mitranisasi hubungan kerjasama antara para pelaku dalam proses produksi dapat bersifat bipartite jika hubungan kerjasama tersebut hanya melibatkan buruh dan pengusaha sendiri, atau bersifat tripartite jika hubungan kerjasama buruh dan pengusaha tersebut melibatkan pemerintah.

Secara historis embrio dari mitranisasi melalui dialog sosial yang bersifat tripartite ini telah berkembang di Perancis sejak 1848, yaitu pada saat terbentuknya Luxembourg Comission yang melibatkan wakil buruh dan pengusaha dalam menentukan kebijakan pemerintah yang berkaitan dengan masalah perburuhan. ${ }^{12}$ Selanjutnya sesudah Perang Dunia Pertama maupun akibat Depresi Dunia 1930, di negara-negara Eropa timbul kesadaran baru tentang pentingnya kerjasama antar para pelaku proses produksi dalam menentukan kebijakan ekonomi dan sosial. Demikian pula pada saat krisis perburuhan melanda Eropa 1980-an, para pelaku dalam proses produksi kembali menyadari pentingnya kerjasama antar mereka. ${ }^{13}$

Para pelaku dalam proses produksi di negara-negara Eropa berupaya untuk mengadakan konsensus di antara mereka.
Konsensus tersebut seianjutnya dijadikan landasan hubungan kerjasama dalam menentukan kebijakan di bidang perburuhan. Pada 1982 di Belanda tercapai konsensus untuk melakukan kerjasama antar para pelaku dalam proses produksi yang dituangkan dalam Wassenaar Agreement. Demikian pula di Denmark pada 1987 tercapai konsensus antara para pelaku dalam proses produksi yang dituangkan dalam Declaration of intent. Selanjutnya di Irlandia juga tercapai konsensus untuk kerjasama di antara para pelaku dalam proses produksi yang dituangkan dalam Program for National Recovery. ${ }^{14}$

Usaha untuk bekerja sama antara para pelaku dalam proses produksi tersebut di atas juga terjadi di Indonesia. Pada 1974, Federasi Buruh Seluruh Indonesia (FBSI) mewakili buruh, Permusyawaratan Urusan Sosial Pengusaha Indonesia/Kamar Dagang dan Industri Indonesia (PUSPI/KADIN) yang mewakili pengusaha, dan Departemen Tenaga Kerja dan Transmigrasi yang mewakili pemerintah, telah mengadakan konsensus nasional yang tertuang dalam Hubungan Perburuhan Pancasila: Hubungan perburuhan tersebut mendasarkan pada prinsip kemitraan yaitu mitra dalam produksi (partner in production), mitra dalam tanggung jawab (partner in resposibility), dan mitra dalam keuntungan (partner in profit).

Dalam prakteknya, pola hubungan perburuhan ini hanya menekankan pada

${ }^{12}$ Anne Trebilock, et.al. 1994. Towards Social Dialogue: Tripartite Cooperation in National Economic and Social Policy-Making. Geneve: International Labour Organization. HIm. 10.

${ }^{13} /$ bid. Hlm. 11.

${ }^{14}$ Peter Auer. "Europe's Employment Revival: four small European countries compared. "ILO Symposium: Social Dialogue and Employment Success. (Geneve, 2-3 March, 1999). Hilm. 39. 
kewajiban kaum buruh untuk bersikap sebagai mitra pengusaha dalam . produksi dan tanggung jawab, sedangkan pengusaha tidak dipaksa untuk memperlakukan buruh sebagai mitra dalam keuntungan. Selanjutnya untuk menciptakan kepastian berusaha dan menarik modal asing, pemerintah tetap mempertahankan berbagai peraturan perundang-undangan yang tujuannya untuk mencegah atau melarang penggunaan hak mogok. Misalnya, Undang-Undang No. 22 Tahun 1957 tentang Penyelesaian Perselisihan Perburuhan yang mempersulit atau secara eksplisit melarang penggunaan mogok, tetap dipertahankan, sedangkan peraturan perundang-undangan yang mempunyai fungsi pendorong terciptanya hubungan kemitraan justru tidak diberlakukan, meskipun belum dicabut. Sebagai contoh Undang-Undang No. 45 PRP Tahun 1960 tentang Dewan Perusahaan beserta peraturan pelaksananya.

Selanjutnya hubungan kerjasama antara buruh dan pengusaha sebagaimana diamanatkan oleh Konvesi maupun Rekomendasi ILO tersebut, tidak hanya dilaksanakan secara tripartite sebagaimana telah diuraikan di atas, namun juga dilaksanakan pada tingkat bipartite sebagaimana akan diuraikan di bawah ini.

Di Jepang, hubungan kerjasama antara buruh dan pengusaha pada tingkat bipartite telah dirintis sejak 1920. Misalnya melalui joint consultation atau melalui peacefull collective bargaining. Meskipun pembentukan joint consultation ini dilakukan oleh pengusaha dan serikat buruh, namun ide joint consultation ini pada awal mulanya berasal dari pemerintah. Oleh pemerintah ide ini dimaksudkan untuk mencegah terjadinya pemogokan. ${ }^{15}$ Setelah Perang Dunia Kedua, joint consultation ini oleh pengurus serikat buruh di tingkat perusahaan dimanfaatkan sebagai sarana untuk meningkatkan hubungan kerjasama yang demokratis. ${ }^{16}$ Selanjutnya pada dewasa ini joint consultation mempunyai fungsi utama untuk menjamin kelangsungan pekerjaan (job security) dan meningkatkan stabilitas usaha. Fungsi-fungsi lainnya antara lain mencakup pertukaran informasi, serta meningkatkan komunikasi selama perundingan tentang halhal yang berkaitan dengan masalah syaratsyarat kerja maupun hal-hal yang bersifat managerial lainnya. ${ }^{17}$ Sebagian besar perjanjian perburuhan tingkat perusahaan di Jepang mencantumkan landasan yuridis joint consultation. ${ }^{18}$ Dengan demikian, joint consultation ini juga berfungsi mendorong terciptanya saling pengertian antar para pihak, sehingga hubungan perburuhan harmonis yang dinamis dapat diciptakan. Melalui perundingan perjanjian perburuhan (collectivebargaining agreement), serikat buruh yang bertindak untuk dan atas nama kaum buruh anggota diikutsertakan dalam menentukan ketentuan-ketentuan baik yang

${ }^{15}$ Mashiro Ken Kuwahara. "Worker Participation in Decisions within Undertakings in Japan." Comparative Labor Law 5. (Winter, 1982, No. 1). Hlm. 55.

ĭlbid. HIm. 57.

${ }^{17} /$ bid. HIm. 64.

${ }^{18}$ Joseph Krislov. "How does the Japanese Industrial Relations System Differ ?" Labor Law Journal 40. (June 1989, No. 6). HIm. 344. 
berkaitan dengan syarat-syarat kerja, misalnya ketentuan-ketentuan tentang upah, jam kerja, cuti, keselamatan kerja, dan jaminan sosial; maupun di luar syarat-syarat kerja, misalnya ketentuan yang mewajibkan kepada serikat buruh untuk mengupayakan agar para buruh anggotanya mematuhi isi perjanjian perburuhan yang telah disepakati.'

Bentuk partisipasi buruh melalui joint consultation di Jepang ini dapat berkembang tanpa ada hambatan yang berarti. Hal ini disebabkan joint consultation di Jepang ini berjalan berdampingan dengan hak berunding kolektif yang menjadi hak serikat buruh. Bahkan joint consultation ini menjadi sarana memperlancar proses perundingan pembuatan atau pembaruan perjanjian perburuhan. Hal-hal yang tidak dapat disepakati dalam joint consultation dilañjutkan melalui perundingan kolektif termasuk dimungkinkannya penggunaan mogok (industrial action/lock out). ${ }^{19} \mathrm{Di}$ samping itu, pengaruh tradisi dan budaya bangsa Jepang yang menekankan pada konsénsus dan hubungan yang harmonis di tempat kerja, telah mendukung perkembangan joint consultation di Jepang. ${ }^{20} \mathrm{Hal}$ ini didasarkan pada dasar filosofi Jepang yang diterapkan di perusahaan. Pertama, Kaizen atau peningkatan yang terus menerus secara perorangan, dalam tim kerja, dalam perusahaan, dan di masyarakat. Jika diterapkan di tempat kerja, berarti peningkatan atau pengembangan standar kerja agar pekerja lebih efisien, lebih menjamin keselamatan, dan lebih mudah untuk dikejakan. Kèdua, Jidoka berarti mengupayakan tercapainya kualitas yang lebih baik. Seseorang harus proaktif mengawasi jalannya pekerjaan agar kualitasnya terjamiń. Ketiga, Wa berarti mengupayakan hubungan yang harmonis antara perusahaan, proses kerja, dan kaum buruh: Hal ini berarti harus selalu menyesuaikan 'diri dengan orang lain dan lingkungan kerja. ${ }^{21}$

Di Inggris, meskipun joint consultation pada masa setelah Perang Dunia Kedua menurun, namun khusus joint consultation yang berkaitan dengan masalah upah, syaratsyarat kerja, kondisi kerja, kesehatan dan keselamatan kerja, kesejahteraan, pensiun, dan pemutusan hubungan kerjà dengan alasan ekonomi, masih tetap berkembang. Pasang surutnya perkembangan joint consutation di Inggris ini dipengaruhi oleh partai yang berkuasa. Dukungan politik terhadap joint consultation ini semakin besar pada saat Partai Buruh berkuasa, dan akan menurun pada saat Partai Konservatif berkuasa. ${ }^{22}$ Pada 1977 Inggris di bawah pemerintahan Partai Buruh memberikan rekomendasi agar wakil buruh di sektor swasta mempunyai suara yang sama dengan para pemegang saham lainnya. Rekomendasi ini mendapat tentangan keras dan tidak pernah dilaksanakan pada saat

${ }^{19}$ Kuwahara. "Undertakings in Japan?" HIm. 52.

${ }^{20} /$ bid. Hlm. 20.

${ }^{2 ' R}$. Lee Creasman, Jr., et.al. "Will the Americans With Disabilities Act Disable Employers?" Labor Law Journal 42. (January 1991, No.1). HIm. 58-59.

${ }^{22}$ Kuwahara. "Undertakings in Japan?" HIm. 6. 
Partai Konservatif berkuasa. ${ }^{23} \mathrm{Hal}$ ini terjadi karena menurut tradisi yang terjadi di Inggris, intervensi pemerintah melalui peraturan perundang-undangan sangat kecil, sehingga keberadaan joint consultation di Inggris lebih didasarkan pada perundingan antara serikat buruh dengan pihak pengusaha, bukan didasarkan pada peraturan perundangundangan yang bersifat publik atau memaksa. ${ }^{24}$

Di Amerika Serikat, partisipasi buruh dalam menentukan upah, jam kerja, kondisi kerja, dan syarat-syarat kerja lainnya dilaksanakan melalui proses perundingan kolektif antara serikat buruh dengan pihak pengusaha. ${ }^{25}$ Upaya untuk membentuk labor management committee yang disponsori oleh FMCS (Federal-Mediation and Conciliation Service), AFL$\mathrm{ClO}$ (American Federation of Labor-Congress of Industrial Organization), dan United States Chambers of Commerce pada tahun 1981 hanya berhasil sementara saja. Ketidakberhasilan dalam membentuk labormanagement committee ini disebabkan oleh sikap skeptis dari para pimpinan serikat buruh dan penolakan atau sikap menentang dari pihak pengusaha untuk membagi hak prerogratifnya-dalam pengambilan putusan yang berkaitan dengan kebijakan perusahaan. ${ }^{26}$ Kekhawatiran yang utama bagi manajemen adalah bahwa manager kehilangan kekuasaannya dalam.mengambil keputusan, terutama pada jajaran supervisor. ${ }^{27}$ Oleh karena itu di Amerika Serikat, Collective Bargaining merupakan bentuk partisipasi buruh yang utama. Hal ini didukung oleh keberadaan serikat buruh yang memiliki pengaruh yang besar dalam penentuan ketentuan upah, jam kerja, syarat-syarat kerja, dan kondisi kerja melalui proses perundingan antara serikat buruh dan pengusaha. ${ }^{28}$

Pada Maret 1993, Presiden Amerika Serikat.mengumumkan pembentukan Komisi tentang Masa Depan Hubungan Buruh dan Pengusaha (The Dunlop Comission). Setelah melakukan fact finding maupun hearing, pada Desember 1994 Komisi ini melaporkan dan membuat beberapa rekomendasi bagi Menteri Tenaga Kerja Amerika Serikat. Dalam kaitan ini antara lain Komisi memberikan rekomendasi agar pemerintah mendorong perkembangan partisipasi buruh (Employee Participation Programs) dalam-menentukan syarat-syarat kerja atau kompensasi lainnya. ${ }^{29}$

Meskipun demikian, pelaksanaan partisipasi buruh di Amerika Serikat tergantung pada apakah kebijakan perusahaan yang akan diputuskan dengan melibatkan buruh atau serikat buruh tersebut masuk dalam kategori

${ }^{23}$ Ronald M. Sharp. "Codetermination: A Postmortem." Labor Law Journal 40 (June 1989, No.6). Hlm. 324. ${ }^{24}$ Kuwahara. "Undertakings in Japan?" Him. 7.

25/bid. HIm. 2.

${ }^{26}$ Ibid. HIm. 24.

${ }^{27}$ Marvin J. Levine. "Labor and Management Response to Total Quality Management." Labor Law Journal 43 (January 1992, No.1). HIm. 110-111.

${ }^{28}$ Kuwahara. "Undertakings in Japan ?" HIm. 4.

${ }^{29}$ Douglas E. Ray, et.al. 1999. Understanding Labor Law. New York: Matthew Bender Company Inc. Him. 156-157. 
permasalahan yang harus dirundingkan, didasarkan pada suatu kesepakatan atau atas tekanan dari buruh atau serikat buruh. Dengan demikian, gagal tidaknya suatu rencana kebijakan perusahaan masuk dalam kategori permasalahan yang harus dirundingkan tergantung pada keberhasilan serikat buruh dalam mengupayakan agar pengusaha menerima untuk memasukan rencana kebijakan perusahaan tersebut menjadi mandatory subject of collective bargaining. ${ }^{30}$

Dalam perkembangannya di Amerika Serikat terdapat perusahaan yang mulai merubah karakteristik hubungan buruh dan pengusaha yang awal mulanya bersifat permusuhan (adversarial relation) menjadi hubungan kerjasama (cooperative relation). Pemerintah Amerika Serikat melalui Departemen Perburuhan mendorong tercapainya Labor Management Cooperation, dengan dasar pertimbangan bahwa lembaga kerjasama ini akan meningkatkan daya saing perusahaan Amerika Serikat, menimbulkan pengaruh yang menguntungkan terutama bagi kepuasan kerja buruh dan meningkatkan produktivitas kerja kaum buruh. ${ }^{31}$ Sebagai salah satu contoh disini misalnya pada 23 Juli 1985 telah tercapai kesepakatan yang revolusioner antara wakil General Motors dengan Serikat Buruh Automotif Amerika Serikat yang dikenal dengan istilah Saturn
Agreement. Tercapainya kesepakatan kerjasama ini didasarkan pada persamaan kepentingan antara pengusaha dan buruh yaitu untuk meningkatkan daya saing hasil produksinya dengan mobil-mobil impor. Atas dasar perjanjian ini, General Motors dan United. Auto Workers setuju untuk menggantikan atau mengubah hubungan permusuhan (adversarial relation) dengan hubungan kerja sama (total cooperative relation). ${ }^{32}$

Melalui Saturn Agreement ini, serikat buruh diikutsertakan dalam perencanaan pengembangan perusahaan. Misalnya setiap penerimaan pegawai baru- harus dikonsultasikan dan diketahui oleh serikat buruh. ${ }^{33}$ Setiap buruh diberi kesempatan untuk memberikan kontribusi dalam memperbaiki kinerja suatu unit atau bagian agar lebih efisien. Tidak ada putusan yang dapat dibuat tanpa persetujuan dari para buruh. Bahkan buruh diberi akses sepenuhnya untuk mengetahui data keuangan dan informasi melalui komputer. ${ }^{34}$

Demikian pula di Irlandia, meskipun pemerintah sangat mendorong partisipasi buruh pada tingkat perusahaan (UnionManagement Cooperation), namun bentuk partisipasi buruh yang berkembang adalah partisipasi buruh melalui proses perundingan (collective bargaining). Hal ini disebabkan $65 \%$

${ }^{30}$ Roy J. Adams. 1995. Industrial Relation Under Liberal Democracy: North American in Comparative Perspective South Caroline: University of South Caroline Press. Hlm. 140.

31Joy K. Renolds. "A Perspective on the Electromation Case From the US Department of Labor." Labor Law Journal 37. June 1992, No.2. Hilm. 397.

${ }^{32}$ Scott Kafker. "Exploring Saturn: An Examination of Philosophy of Total Labor Management Cooperation and Limitation Presented by the NLRA." The Labor Lawyer 5 (Fall 1989, No.4). HIm. 703-704.

33/bid. HIm. 706.

${ }^{34}$ Jbid. HIm. 712. 
buruh-buruh di Irlandia adalah anggota serikat buruh, sehingga yang duduk sebagai wakil buruh dalam Union-Management Cooperation adalah para pengurus serikat buruh. Selanjutnya untuk mencegah terjadinya conflict of interest, para wakil buruh tersebut meninggalkan jabatannya sebagai pengurus serikat buruh. ${ }^{35}$

Sejalan dengan perkembangan bentuk partisipasi buruh di Irlandia di atas, partisipasi buruh di Canada juga masih terbatas pada bentuk perundingan kolektif, karena kemungkinannya sangat kecil bagi pengusaha maupun serikat buruh di Canada menerima lembaga co-determination yang berasal dari Jerman tersebut. Meskipun demikian di provinsi Quebec yang memiliki pengalaman dalam menerapkan Worker Co-management. ${ }^{36}$

Di Indonesia, pada masa pemerintahan Soekarno melalui Undang-Undang No. 45 PRP Tahun 1960 tentang Dewan Perusahaan, pemerintah bermaksud untuk membentuk wadah kerja sama antara buruh dan pengusaha dalam melaksanakan kegiatan usaha melalui Dewan Perusahaan. Falsafah pembentukan Dewan Perusahaan menurut undang-undang ini adalah untuk mengikut sertakan unsur - unsur dalam masyarakat dan unsur-unsur dalam perusahaan itu sendiri. Dengan demikian, tujuan Dewan Perusahaan adalah menyelenggarakan ekonomi gotong royong atau ekonomi kolektif antara para peserta produksi dan masjyarakat. Sejak diundangkan, undang-undang yang dimaksudkan untuk mewujudkan dewan- dewan yang berkewajiban membantu pimpinan perusahaan dalam rangka mempertinggi produksi di perusahaan-perusahaan negara ini, tidak pernah efektif hingga saat ini, meskipun undang-undang tersebut beserta peraturan pelaksananya yaitu Peraturan Pemerintah No. 25 Tahun 1961 belum pernah dicabut. Peraturan Pemerintah ini pada dasarnya mengatur bahwa di tiap-tiap perusahaan negara agar segera dibentuk Dewan Perusahaan dengan ketentuan mendapat persetujuan dari Menteri Perburuhan. Oleh karena itu, bentuk partisipasi buruh dalam penentuan kebijakan perusahaan di Indonesia masih terbatas pada partisipasi buruh melalui perundingan kolektif. Hal ini didasarkan pada Undang-undang No. 21 Tahun 1954 tentang Perjanjian Perburuhan. Meskipun kaum buruh melalui serikat buruh memiliki hak untuk menentukan upah, syarat-syarat kerja, dan kondisi kerja lainnya; namun jika dilihat dari isi perjanjian perburuhan yang ada, pada umumnya sebagian besar pasal-pasal yang tercantum dalam perjanjian perburuhan sama persis dengan pasal-pasal yang tertuang dalam peraturan perundang-undangan yang berlaku. Keadaan demikian ini terjadi karena di satu pihak campur tangan pemerintah melalui berbagai ketentuaan perburuhan sangat besar, di lain pihak bargaining power serikat buruh di Indonesia pada umumnya masih lemah. Banyaknya ketentuan tentang upah, syaratsyarat kerja, dan kondisi kerja lainnya yang ditetapkan oleh pemerintah, telah menciptakan situasi yang tidak kondusif

${ }^{35}$ Kuwahara. "Undertakings in Japan?" HIm. 7.

${ }^{36} \mathrm{lbid}$. HIm. 5. 
terhadap perkembangan partisipasi buruh di tempat kerja. Dengan demikian; partisipasi buruh dalam menentukan kebijakan perusahaan yang bersifat managerial masih belum berkembang di Indonesia.

- Hal ini berbeda dengan Jerman, yang memberikan kesempatan kepada kaum buruh untuk ikut serta memecahkan masalahmasalah perburuhan yang krusial khususnya masalah pengupahan, serta dalam menentukan kebijakan perusahaan. Misalnya dalam kaitan dengan masalah upah, masalah penerimaan pegawai, pemutusan hubungan kerja, merger, dan perubahan struktur organisasi perusahaan, tempat kerja, dan pelatihan kerja. ${ }^{37}$

Partisipasi buruh dalam ikut serta menentukan kebijakan perusahaan (workers participation) di Jerman ini, untuk pertama kalinya diatur dalam Industrial Code Tahun $1848 .{ }^{38}$ Kelahiran undang-undang yang mengatur masalah partisipasi buruh dalam menentukan kebijakan perusahaan ini diusulkan oleh kelompok konservatif di Parlemen pada waktu itu. Awalnya, upaya untuk. membuat undang-undang ini mendapat tantangan berat dari kelompok Sosial Demokrat yang didukung oleh Serikat Buruh Jerman. ${ }^{39}$ Dengan demikian, ide untuk membentuk Dewan Perusahaan di Jerman bukan didorong oleh gerakan buruh, melainkan justru disponsori para pengusaha..$^{40}$

Serikat buruh Jerman yang pada awal mulanya menolak kehadiran. Dewan Perusahaan yang tidak melibatkan serikat buruh di dalamnya, pada perkembangan selanjutnya serikat buruh merubah strateginya dari revolutionary strategic ke reformistic strategy. ${ }^{41}$ Selanjutnya mereka mulai mendukung ide tentang partisipasi buruh pada tingkat perusahaan, dengan catatan bahwa kegiatan partisipasi buruh ini di bawah pengawasan serikat buruh: Oleh karena itu, serikat buruh berusaha memecahkan masalah ini dengan memperluas peran Dewan Perusahaan, khususnya yang berkaitan dengan bidang ekonomi. Di samping itu, serikat buruh juga mengupayakan agar pengurus serikat buruh duduk dalam Dewan Perusahaan.

$\mathrm{Hal}$ ini tercermin dalam perkembangan peraturan perundang-undangan yang mengatur masalah partisipasi buruh dalam menentukan kebijakan perusahaan dari 1848 , tepatnya pada saat diundangkannya Industrial Code Tahun 1848, yang selanjutnya disempurnakan melalui Amandment Industrial Code Tahun 1891. Perkembangan nyata dalam mencapai bentuknya sebagai Dewan Perusahaan sebagaimana dikenal pada saat

${ }^{37}$ Rheinhard Richardi. "Worker Participation in Decisions Within Undertakings in The Federal Republic of Germany." Comparative Labor Law 5. (Winter 1982, No.1). HIm. 36-37.

${ }^{38}$ Gunter Halbach, et. al. 1994. Labour Law in Germany: An Overview. Eva Maria Forster, trans. 5th. ed. Bonn: Federal Minitry of Labour and Social Affairs. HIm. 344.

${ }^{39}$ Manfred Weis. 1987. Labour Law and Industrial Relations in the Federal Republic of Germany, (Frankfurt, Boston, and New York: Kluwer Law and Taxation Publishers. HIm. 27.

solbid.

${ }^{41}$ /bid. 
ini terjadi sejak diundangkannya Works Council Act Tahun 1920 (Betriebstaatzgezetz) ${ }^{42}$

Selanjutnya di Swedia selama 1970-an, partisipasi buruh dalam menentukan kebijakan perusahaan yang sudah diperkenalkan sejak 1946, menjadi bahan perdebatan publik. Di Swedia terdapat tiga bentuk partisipasi buruh dalam penetapan kebijakan atau keputusan perusahaan, yaitu partisipasi buruh tingkat tempat kerja (Shopfloor Participation), partisịpasi buruh tingkat perusahaan (Company Participation), dan partisipasi buruh di bidang keuangan (Financial Participation). ${ }^{43}$ Melalui Company Participation dan Financial Participation ini, para buruh Swedia melalui wakilnya mempunyai hak suara yăng sama dengan pemilik saham lainnya. ${ }^{44} \mathrm{Hal}$ ini memberikan petunjuk bahwa bentuk kerjasama antara buruh dan pengusaha ini juga terjadi pada tingkat Dewan Komisaris Perusahaan (Supervisory Boards). Melalui kerjasama antara buruh dan pengusaha di tingkat Dewan Komisaris ini, buruh diikutsertakan dalam memberikan pandangan atau masukan kepada perusahaan dalam menentukan putusanputusan perusahaan (managerial decision making). Dengan demikian, melalui mekanisme hubungan kerjasama konsultasi ini, kaum buruh di Swedia dapat mengetahui atau memberikan saran dalam kaitannya dengan rencana akan digunakannya peralatan atau mesin baru, rencana produksi, serta hal yang berkaitan dengan job security sebagai akibat dari perubahan teknologi yang dilakukan oleh pengusaha. ${ }^{45}$ Dalam hal ini juga termasuk membicarakan masalah perburuhan yang krusial terutama masalah upah, kondisi kerja, dan syarat-syarat kerja yang erat kaitannya dengan peningkatan kualitas hidup. ${ }^{46} \mathrm{Hal}$ ini tercermin dalam Act on Co-determination at Work 1977.47

Di Belanda, berdasarkan Undang-undang Dewan Perusahaan (Wet op de Ondernemingsraden) Tahun 1950, buruh mempunyai hak untuk duduk sebagai perwakilan buruh dalam Dewan Perusahaan. ${ }^{48}$ Keikutsertaan buruh dalam pengambilan keputusan (co-determination) sebenarnya telah eksis sejak berakhirnya Perang Dunia Kedua, dan sejak 1971. Dewan Perusahaan wajib dibentuk di perușahaanperusahaan yang mempekerjakan buruhnya lebih dari tigapuluh lima orang. Sedangkan perusahaan-perusahaan kecil yang mempekerjakan buruh antara sepuluh sampai dengan tiga puluh lima orang tidak terkena kewajiban untuk membentuk Dewan

${ }^{42}$ Richardi "The Federal Republic of Germany." HIm. 28.

${ }^{43} T$ The Swedish Institute. "Labour Relation in Sweden." Fact Sheet on Sweden. (January, 2001). HIm. 3.

${ }^{44} \mathrm{David} \mathrm{H}$. Brody, et. al. "Alternative to the United States System of Labor Relations: A Comparative Analysis of the Labor Relations Systeem in the Federal Republic of Germany, Japan, and Sweden." Vanderbilt Law Review 41. (Winter 1988, No.3). HIm. 264.

${ }^{45}$ Olof Berqvist. "Worker Participation in Decisions within Undertakings in Sweden." Comparative Labor Law 5. (Winter 1982, No.1). HIm. 65.

${ }^{46}$ Kuwahara. "Undertakings in Jerman. "HIm. 53.

${ }^{47}$ The Swedish Institute. "in Sweden." HIm. 3.

${ }^{48}$ H.L. Bakels. 1977. Arbeidsrechtelijke geschriften 1962 - 1977, Kluwer-Deventer. HIm. 419. 
Perusahaan. ${ }^{49}$ Anggota Dewan Perusahaan dari unsur buruh pada umumnya mempunyai latar belakang pengalaman sebagai' pengurus serikat buruh. Selanjutnya kedudukan Dewan Perusahaan di Belanda berada di samping serikat buruh.

Di Spanyol, partisipasi buruh yang dijamin sejak 1980 melalui Company Committees in Workplace. ${ }^{50} \mathrm{Di}$ Italia, hak partisipasi buruh dalam menentukan kebijakan perusahaan tercantum dalam Konstitusi Tahun $1948 . .^{51} \mathrm{Di}$ Argentina, jaminan yuridis dari partisipasi buruh ini tercantum dalam Konstitusi yang menyatakan: "the law shall ensure to the worker ..... a share in the eamings of enterprises, with control of production and collaboration in management. ${ }^{52}$

Di Israel, pelaksanaan partisipasi buruh tercermin dalam Joint Management yang terdiri dari tujuh manajer, dimana tiga orang manajer dipilih oleh pengusaha, dua orang manajer dipilih dari buruh krah putih (white collar worker), dua orang manajer lainnya dipilih dari buruh krah biru (blue collar worker). Selanjutnya $1 / 3$ anggota Dewan Direktur berasal dari buruh yang dipilih oleh Serikat Buruh Tingkat Nasional.53 Akhirnya di India partisipasi buruh dalam penetapan kebijakan perusahaan tercermin dalam Joint Management Council. ${ }^{54}$

\section{Kepemilikan Saham Buruh melalui} Employee Stock Ownership Plan

Selain melalui institusi Co-determination yang memberikan kesempatan kepada buruh untuk berpartisipasi dalam penentuan kebijakan perusahaan sebagaimana telah diuraikan di atas, mitranisasi hubungan buruh dan pengusaha juga dapat dilaksanakan melalui program kepemilikan sebagian saham oleh kaum buruh (Employee Stock Ownership Plan). Kepemilikan saham perusahaan oleh kaum buruh ini akan menumbuhkan rasa memiliki kaum buruh terhadap perusahaan (sense of belonging) dan rasa tanggung jawab terhadap jalannya perusahaan (sense of resposibility), pada gilirannya akan meningkatkan produktivitas kerja dan meningkatkan kemajuan perusahaan. Dengan kata lain tujuan akhir dari program kepemilikan saham ini bukan semata-mata memiliki perusahaan, tetapi pengawasan buruh terhadap jalannya perusahaan, demokratisasi dalam proses produksi, dan menghilangkan ketidaksamaán kedudukan buruti dan pengusäaha. ${ }^{55}$

Di Amerika 'Serikat, realisasi prinsip kemitraan dalam keuntungan ini tercermin dalam ESOPs (Employee Stock Ownership Plans). Melalui ESOP ini, buruh-buruh di Amerika Serikat dapat memiliki saham biasa

\footnotetext{
${ }^{49}$ H.L. Bakels. 1987. Nederlandsarbeidsrecht. Kluwer-Deventer. HIm. 244-245.

50/bid. Him. 15.

51Sharp. "A postmortem." HIm. 325.

52.Merrifield. "Within Undertakings."Hlm. 17.

${ }^{53} /$ bid. HIm. 19.

${ }^{54} /$ bid.

${ }^{55}$ Julie Lynn Kaufman. "Democratic ESOPs: Can Workers Control Their Future?" The Labor Lawyer 5.
} (Fall 1989, No.4). HIm. 1. 
atau saham istimewa perusahaan dimana mereka bekerja. ${ }^{56}$ Sampai pertengahan 1970 . an pada umumnya serikat buruh di Amerika menolak konsep ESOPs. Beberapa serikat buruh Amerika Serikat baru aktif berpartisipasi dalam ESOPs pada 1990.57

Penolakan serikat burut Amerika Serikat terhadap konsep ESOPs ini didasarkan pada dua pertimbangan. Pertama, banyak perusahaan pada masa lampau yang benarbenar anti terhadap gerakan buruh. Oleh karena itu, jika buruh diberi kesempatan untuk mengadakan kolaborasi dengan pengusaha melalui program kepemilikan saham, maka hal ini merupakan suatu yang tidak sejalan dengan posisi buruh dalam proses perundingan yang bersifat permusuhan. Dengan kata lain, serikat buruh berpandangan bahwa melalui program kepemilikan saham ini, gerakan buruh dikooptasi oleh pengusaha. Kedua, buruh menyadari sepenuhnya bahwa beban kerugian perusahaan sebagai akibat menurunnya harga saham juga akan dirasakan olèh kaum buruh yang ikut serta dalam program kepemilikan saham. ${ }^{5 B}$

Selanjutnya dilihat dari perkembangan ESOPs sejak 1975 dari kurang lebih 'dua ratus perusahaan telah bertambah menjadi sepuluh ribu perusahaan. ESOPs di perusahaanperusaahaan tersebut telah mengikut sertakan sepuluh juta buruh dengan kepemilikan saham rata-rata berkisar antara $15 \%$ sampai dengan $35 \%$ saham perusahaan pada $1994 . .^{59}$ Sebagai contoh dapat dikemukakan buruhburuh Chrysler memiliki $15 \%$ saham perusahaan, $32 \%$ saham Western berada di tangan buruh-buruhnya, $50 \%$ saham Rath berada di tangan buruh-buruhnya, bahkan buruh-buruh Weirton Steel saat ini adalah pemilik seluruh saham perusahaan (100\%). ${ }^{60}$ Program kepemilikan saham perusahaan-di Amerika Serikat ini telah meningkatkan efisiensi perusahaan. Misalnya di salah satu perusahaan penerbangan di Amerika Serikat, dalam jangka waktu satu tahun pelaksanaan program kepemilikan saham ini telah meningkatkan produktivitas buruh rata-rata $5 \%$ per tahun. Di lain pihak, program kepemilikan saham ini telah menyelamatkan perusahaan Rath dari kesulitan keuangan perusahaan. ${ }^{61}$

Di Indonesia, meskipun sudah terdapat Undang-Undang No. 1 Tahun 1995 tentang Perseroan Terbatas yang memberikan hak kepada buruh untuk.membeli saham pada saat perusahaan dimana ia bekerja, membutuhkan penambahan modal. Hak buruh untuk membeli saham sebagaimana diatur dalam Pasal 36 dan Pasal 51 UndangUndang No. 1 Tahun 1995.tentang Perseroan Terbatas tersebut dirumuskan sedemikian rupa, sehingga buruh memiliki kesempatan yang sangat kecil untuk melaksanakannya.

56Joseph R. Blasi \& Douglas L. Kruse. "Strategic Problems and Tactical Promise: Unions and Employee Ownership." Labor Law Journal 42. (Spring 1991, No: 8). HIm. 400.

${ }^{57}$ Arthur A. Sloane \& Fred Witney. 1994. Labor Relations, 8th. ed. New Jersey: Prentice Hall. HIm. 444.

58/bid.

59/bid. HIm. 448 .

${ }^{60}$ bid. HIm. 447.

${ }^{6}$ ibid. Him. 448. 
Bahkan, hingga saat ini buruh belum dapat menggunakan haknya untuk membeli saham sebagaimana diatur dalam Pasal 36 dan Pasal 51 Undang-Undang No. 1 Tahun 1995 tentang Perseroan Terbatas, karena peraturan pelaksanaannya belum ditetapkan. Kesempatan yang sangat kecil bagi buruh yang hendak menggunakan haknya membeli saham perusahaan tercermin dalam Pasal 36 Undang-Undang No. 1 Tahun 1995 tentang Perseroan Terbatas yang menentukan:

(1). Dalam hal Anggaran Dasar tidak menentukan lain, seluruh saham yang dikeluarkan dalam penambahan modal harus terlebih dahulu ditawarkan kepada setiap pemegang saham seimbang dengan pemilikan saham untuk klasifikasi saham yang sama.

(2). Dalam hal pemegang saham tidak menggunakan hak untuk membeli saham sebagaimana dimaksud dalam ayat (1), setelah lewat 14 hari terhitung sejak penawaran, perseroan menawarkan kepada karyawan mendahului penawaran kepada orang lain untuk membeli jumlah tertentu atas saham tersebut.

(3). Ketentuan mengenai saham yang ditawarkan kepada karyawan sebagaimana dimaksud dalam ayat (2) diatur lebih lanjut dengan Peraturan Pemerintah.

Ketentuan Pasal 36 ayat (1) UndangUndang No. 1 Tahun 1995 tentang Perseroan Terbatas sebagaimana dipaparkan di atas, dengan jelas menggariskan bahwa buruh tidak pernah akan dapat memiliki saham perusahaan, jika Anggaran Dasar perusahaan tersebut tidak membuka kesempatan bagi buruh untuk membeli saham perusahaan. Selanjutnya buruh tetap tidak akan pernah dapat memiliki saham perusahaan, meskipun - Anggara Dasar Perusahaan tersebut memberikan hak kepada buruh untuk memiliki saham selama peraturan pelaksananya belum ditetapkan oleh pemerintah sebagaimana diatur dalam Pasal 36 ayat (3) Undang-Undang No. 1 Tahun 1995 tentang Perseroan Terbatas. Materi yang serupa dengan Pasal 36 Undang-Undang No. 1 Tahun 1995 tentang Perseroan Terbatas ini dapat ditemukan dalam Pasal 51 Undang-Undang No: 1 Tahun 1995 tentang Perseroan Terbatas, yang menetapkan:

(1). Dalam hal Anggaran Dasar mengharuskan pemegang saham menawarkan terlebih dahulu usahanya kepada kelompok pemegang saham tertentu atau pemegang saham lainnya yang tidak dipitihnya sendiri, perseroan wajib menjamin bahwa semua saham yang ditawarkan dibeli dengan harga yang wajar dan dibayar secara tunai dalam waktu 30 hari terhitung sejak penawaran dilakukan.

(2). Dalam hal perseroan tidak dapat menjamin terlaksananya ketentuan sebagaimana dimaksud dalam ayat (1), para pemegang saham dapat diberi kesempatan untuk menawarkan dan menjual sahamnya kepada karyawan mendahului penawaran kepada orang lain.

(3) Ketentuan mengenai penawarản dan penjualan saham kepada karyawan sebagaimana yang dimaksud ayat (2) diatur lebih lanjut dengan Peraturan Pemerintah. 
Dengan demikian, peraturan pelaksanaan dari Pasal 36 ayat (3) dan Pasal 51 UndangUndang No. 1 Tahun 1995 tentang Perseroan Terbatas menempati posisi penting untuk mengoperasionalkan kedua pasal tersebut.

\section{Simpulan}

Hubungan kemitraan antara buruh dạn pengusaha yang didasarkan pada hubungan perburuhan yang mengedepankan partisipasi buruh dalam menentukan kebijakan perusahaan baik yang terkait dengan masalah syarat-syarat atau kondisi kerja maupun masalah-masalah yang bersifat managerial hanya akan terjadi jika buruh ditempatkan. pada posisi sentral. Hubungan kerjasama ini pada gilirannya akan mendorong terciptanya situasi.yang kondusif bagi penyelesaian secara damai terhadap masalah perburuhan yang krusial khususnya masalah upah. Dalam kondisi demikian, para pelaku proses produksi lebih menekankan pada hubungan perburuhan koalisi. Pada tingkat praksis hubungan perburuhan di Indonesia dewasa ini masih belum mencapai tingkat hubungan koalisi, melainkan masih berada pada tingkat hubungan perburuhan konflik. Untuk itu perlu adanya kemauan para pihak yang menjadi unsur produksi untuk merubah pola hubungan perburuhan konflik ke pola hubungan perburuhan koalisi.

Menempatkan buruh pada posisi pinggiran (marginalization), berarti memperuncing benih konflik yang melekat pada hubungan buruh pengusaha yang memiliki kecenderungan terjadinya konflik. Hal ini membawa konsekwensi terhadap penyelesaian persoalan yang krusial khususnya masalah upah dan kesejahteraan lainnya sulit didekati melalui cara-cara damai. Dalam kondisi demikian, para pelaku dalam proses produksi menempatkan diri pada pola hubungan perburuhan konflik (Conflict Arbeidsverhoudingan-model). Hubungan perburuhan konflik yang terjadi di Indonesia sebagai negara berkembang, akan mengganggu pertumbuhan ekonomi nasional serta menghambat peningkatan kesejahteraan kaum buruh itu sendiri. Untuk itu peran pemerintah diperlukan untuk membantu perubahan dari pola hubungan perburuhan konflik ke pola hubungan perburuhan koalisi.

Pemerintah sebagai pihak yang berkepentingan atas kemajuan ekonomi nasional serta peningkatan kesejahteraan rakyat khususnya kaum buruh, menempati posisi strategis dalam menciptakan situasi yang kondusif bagi terwujudnya hubungan kemitraan buruh dan pengusaha yang didasarkan pada hubungan perburuhan yang demokratis dan partisipatif. Disamping itu, pemerintah juga harus proaktif dalam mencegah timbulnya perselisihan yang terkait dengan masalah perburuhan yang krusial khususnya yang berkaitan dengan masalah pengupahan. Tindakan proaktif ini dapat dilakukan melalui tim task-force.

Untuk menciptakan situasi yang kondusif bagi hubungan kemitraan buruh dan pengusaha, pemerintah wajib menetapkan peraturan perundang-undangan yang mengatur hak dan kewajiban buruh maupun pengusaha dalam menentukan upah, kondisi kerja, dan syarat-syarat kerja lainnya, melalui berbagai forum kerjasama buruh dan pengusaha. Hal ini penting untuk mendorong terciptanya demokrasi di tempat kerja, agar partisipasi buruh dalam menentukan 
kebijakan perusahaan dapat berkembang. Dengan demikian, pemerintah tidak perlu terlalu banyak campur tangan dalam menentukan hukum perburuhan materiil. $\sqsupset$

\section{Daftar Pustaka}

Adams; Roy.1995. Industrial Relations Under - Liberal Democracy: North America in Comparative Perspective. Columbia, South Carolina: University of South Carolina Press.

American Society for Training and Development: 1992. "America and The New Economy." Montly Labor Review 115 (February), No..2.

Auer, Peter. 1999. "Europe's Employment Revival: four small European countries compared." Geneve: ILO Symposium: Social Dialogue and Employment Success.

Bakels, HL. 1987. Schets van Nederlands Arbeidsrecht. Kluwer, Deventer.

Bergqvist, Olof. 1982. "Worker Participation in Decisions Within Undertakings in Sweden." Comparative Labor Law 5 (Winter), No.1.

Blasi, Joseph R. and Douglas L Kruse. 1991. "Strategic Problems and Tactical Promise: Unions and Employee Ownership." Labor Law Journal 42 (Spring), No. 8.

Brody, David H. et. al. 1988. "Aalternaaative to the United States System of Labor Reelations: A Comparativ Analysis of the Labor Relations System in the Federal Republic of Germany, Japan, and
Sweden." Vanderbilt Law Revies 41 (Winter), No. 3.

Compa, Lance. 1993. "Labor 'Standard in International Trade." Law and Policy in Internationaal Business 25 (Fall), No. 1.

Creasman, R. Lee. 1991. Will the American With Disabilities Act Disaable Employers? - Labor Law Journal 42 (January), No: 1.

Direktur Jendèral Binawas Depnảkeŕ, Laporan Perkembangan Pemogokan di Indonesia . Tahun 1995 sampai dengan April 2000.

Halbach, Gunter, et.al. 1994. Labor Law in Germany: An Overview. trans., Eva Maria Foster, et.al.Bonn: Federal Ministry of Labor and Social Affairs.

Hernstadt, Owen E. 1992. "Whay Some Union Hesitate to Participate in LaborManagement Cooperative Programs. The Labor Lawyer 8 (Winter), No. 1.

Kafker, Scott. 1989. "Exploring Saturn: An Examination of the Philosophy of "Total" Labor Management Cooperation and the Limitations Presented by NLRA". The Labor Lawyer 5 (Fall), No. 4.

Kaufman, Julie Lynn. 1989. "Democratic ESOP's: Can Workers Control Their Future?" The Labor Lawyer 5 (Fall), No. 4.

Kompas, 5 November 2001, 23 November 2001, 14 Desember 2001.

Krislov, Joseph. 1989. "How does the Japanese Industrial Relations System Differ?" Labor Law Journal 40 (June), No. 6. 
Kuwahara, Mashiro Ken, 1982. "Worker Participation in Decisions Within Undertakings in Japan." Comparative Labor Law 5.(Winter), No. 1.

Levine, Marvin J. 1992. "Labor and Management response to Total Quality Management," Labor Law Journal 43 (January), No. 1.

Merrifield, Leroy. 1982. "Worker Participation in Decisions Within Undertakings." Comparative Labor Law 5 (Winter), No. 1.

Ray, Douglas E., Calvein William Sharpe \& Robert N Strassfeld. 1999. Understanding Labor Law, New York and San Franscisco: Methew Bender \& Co.,Inc.

Reynolds, Joy K. 1992: "A Perspective on the Electromation Case From the.US Department of Labor." Labor Law Journal 37 (June), No. 2.

Richardi, Rheinhard. 1982. "Worker Participation in Decision Within Undertakings in
The Federal Republic of Germany." Comparative Labor Law 5 (Winter), No. 1.

Rockefeller, John D jr. 1996. "Cooperation in Industry." The International Labour Review 135, No. 3-4.

Sharp, Ronald M. 1989: "Codetermination: A Postmortem." Labor Law Journal 42 (August), No. 6: Sloane, Arthur A. 1994. Labor Relations. New Jersey: Prentice Hall.

The Swedish Institute. 2001. "Labour Relation in Sweden." Fact Sheet on Sweden (January).

Trebilock, Anne, et.al. 1994 Towards Social Dialogue: Tripartite Cooperation in National Economic and Social Policy-Making. Geneve: International Labour Organization.

Weis, Manfred. 1982. Labor Law and Industrial Relations in the Federal Republic of Germany. New York: Kluwer Law \& Taxation Publishers. 